\title{
The effect of corticotrophin zinc on plasma 17-hydroxycorticoids as a test of adrenal cortical function
}

\author{
BY \\ J. S. JENKINS \\ From the Medical Unit, St. George's Hospital, London
}

SYNOPSIS The response of plasma 17-hydroxycorticoids to corticotrophin has been determined using a simplified technique. Steroid levels appeared to be maximal four hours after the injection of 40 units of corticotrophin zinc. No response was obtained in cases of Addison's disease and a sluggish increase occurred in hypopituitarism. The effect of steroid therapy is discussed.

The response of 17, 21-dihydroxy-20-ketosteroids (17-hydroxycorticoids) in the plasma to the administration of corticotrophin provides a direct and sensitive measure of adrenal cortical function (EikNes, Sandberg, Nelson, Tyler, and Samuels, 1954; Eik-Nes, Sandberg, Migeon, Tyler, and Samuels, 1955; Bayliss and Steinbeck, 1954). The widespread use of this procedure has been limited, however, by the technical complexity of the methods available for the estimation of plasma 17-hydroxycorticoids. The method of Nelson and Samuels (1952), which has been mostly favoured, involves the need for column chromatography with specially prepared florisil, making it unsuitable for ordinary laboratory use. A method which dispensed with the need for chromatography was subsequently devised by Silber and Porter (1954), and more recently Peterson, Karrer, and Guerra (1957) have further modified the SilberPorter procedure, so that the estimation of plasma 17-hydroxycorticoids has now become greatly simplified.

For the adequate assessment of its function, prolonged stimulation of the adrenal cortex is necessary. An intravenous infusion of corticotrophin for six or eight hours is often used but this is inconvenient and is occasionally accompanied by hypersensitivity reactions, especially if given repeatedly to a patient suffering from adrenal insufficiency. Long-acting forms of corticotrophin for intramuscular use are easier to administer and are now more consistently reliable than formerly. Geller, Gabrilove, and Soffer (1957) and Jenkins (1958) have shown that a single injection of the aqueous corticotrophin zinc prepara-

Received for publication 28 April 1960. tion is followed by a very prolonged increase in 17-hydroxycorticoid secretion. It seemed, therefore, that the estimation of plasma 17-hydroxycorticoid levels by the Peterson technique before and after the injection of corticotrophin zinc would provide a relatively simple test of adrenal cortical function.

\section{METHODS}

Twenty-five millilitres of blood was taken from the patient between 9.30 and 10.0 a.m. and transferred to a bottle containing heparin. The plasma was separated immediately and frozen until required. An injection of $\mathbf{4 0}$ units of corticotrophin zinc was given intramuscularly and four hours later a further sample of blood was taken. In some cases the test was repeated on the following day.

ESTIMATION OF PLASMA 17-HYDROXYCORTICOIDS The method of Peterson et al. (1957) was used with slight modifications. This method involves the extraction of $5 \mathrm{ml}$. plasma with methylene chloride, washing the extract with dilute alkali, and shaking with the phenylhydrazinesulphuric reagent of Porter and Silber (1950). Colour development is read at $410 \mathrm{~m} \mu$ and suitable blanks are incorporated to allow for non-specific colour due to the acid alone. Steroids, other than hydrocortisone, having the 17, 21-dihydroxy-20-keto structure, are also estimated by this procedure but Peterson, Wyngaarden, Guerra, Brodie, and Bunim (1955) have shown, both by counter-current and paper chromatographic methods, that over $90 \%$ of the phenylhydrazine-reacting material is ordinarily hydrocortisone. Certain drugs, such as chloral, quinine, and paraldehyde, interfere with the colour reaction and should not be given before carrying out the test.

The following details refer to modifications of the original method. Methylene chloride was purified by 
washing first with concentrated sulphuric acid, then with water, drying with anhydrous sodium sulphate, and distillation through a fractionating column. Instead of swirling the plasma with methylene chloride as originally described by Peterson, extraction was more conveniently performed by shaking it vigorously in a glass stoppered tube for five minutes; emulsions were easily broken by centrifugation. The methylene chloride extract was shaken with $0.6 \mathrm{ml}$. phenylhydrazine-sulphuric acid reagent, the methylene chloride was removed, and the reagent allowed to stand at room temperature overnight. The optical density was then read at $410 \mathrm{~m} \mu$ in microcuvettes of $0.5 \mathrm{ml}$. capacity and $10 \mathrm{~mm}$. light-path, using a Unicam S.P. 600 spectrophotometer, the carrier of which had been specially adapted. (An attachment enabling micro-cuvettes to be used with the S.P. 600 instrument is shortly to be made available by Unicam Instruments Ltd.)

The recovery of hydrocortisone added in amounts of $1.0 \mu \mathrm{g}$ and $2.0 \mu \mathrm{g}$ is shown in Table $\mathrm{I}$.

\section{TABLE I}

RECOVERY OF HYDROCORTISONE ADDED TO PLASMA

17-Hydroxycorticoids ( $\mu$ g. per $5 \mathrm{ml}$. plasma)

\begin{tabular}{ccc}
\hline Plasma & $\begin{array}{c}\text { Plasma }+1.0 \mu \mathrm{g} . \\
\text { Hydrocortisone }\end{array}$ & $\begin{array}{c}\text { Plasma }+2.0 \mu \mathrm{\mu g} \\
\text { Hydrocortisone }\end{array}$ \\
\hline 0.58 & 1.52 & 2.30 \\
0.51 & 1.48 & 2.30 \\
0.61 & 1.50 & 2.29 \\
0.57 & 1.57 & 2.34 \\
0.61 & - & 2.42 \\
0.57 & - & 2.37 \\
Mean 0.58 & 1.51 & 2.34 \\
Mean recovery & $0.93(93 \%)$ & $1.76(88 \%)$
\end{tabular}

\section{RESULTS}

NORMAL RESPONSE The figure shows the plasma 17-hydroxycorticoid levels at two-hourly intervals up to six or eight hours after the administration of 40 units of corticotrophin zinc to four normal individuals. The maximum increase occurred at four to six hours after the injection and in all subsequent tests the four-hour level was used.

The response of 20 patients without evidence of

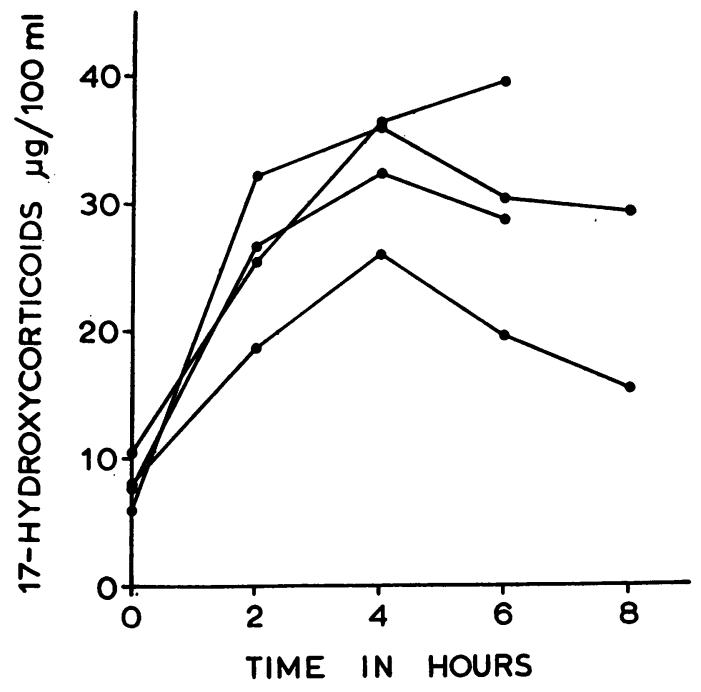

FIG. 1. The effect of $\mathbf{4 0}$ units of corticotrophin zinc on the plasma 17-hydroxycorticoids in four normal persons.

endocrine disease showed control levels which ranged from $5 \mu \mathrm{g}$. to $28 \mu \mathrm{g}$. per $100 \mathrm{ml}$. (mean 13 $\mu$ g. S.D. \pm 6$)$ and four hours after corticotrophin the values were $21 \mu \mathrm{g}$. to $53 \mu \mathrm{g}$. (mean $35 \mu \mathrm{g}$. S.D. \pm 8 )

ADDISON's DISEASE The application of this test to five patients suffering from Addison's disease is shown in Table II. In four cases the control values were low or absent and there was no significanp response to corticotrophin. In case M.W. the clinicat appearance was suggestive of Addison's disease, as shown by increased pigmentation and undue weak $\overline{3}$ ness, but the control level was normal. A lack of response to corticotrophin, however, which was con $\frac{\text { O }}{3}$ firmed by comparable urinary steroid findings indicated a partial adrenal insufficiency. This condition has been described by Eik-Nes et al. (1955 and Abu Haydar, St. Marc, Reddy, Laidlaw, anc.

TABLE II

RESPONSE OF PLASMA 17-HYDROXYCORTICOIDS IN ADRENAL INSUFFICIENCY

Case Age Dex Diagnosis

Plasma 17-Hydroxycorticoids ( $\mu \mathrm{g}$. per $100 \mathrm{ml}$.)

\begin{tabular}{|c|c|c|}
\hline Control & $\begin{array}{l}\text { A.C.T.H. } \\
\text { (1st day) }\end{array}$ & $\begin{array}{l}\text { A.C.T.F } \\
\text { (2nd dayg }\end{array}$ \\
\hline
\end{tabular}

\begin{tabular}{llll}
\hline F.D. & 52 & F & Addison's disease \\
A.P. & 36 & F & Addison's disease \\
E.G. & 36 & F & Addison's disease \\
D.W. & 47 & F & Addison's disease \\
M.W. & 48 & F & Partial Addison's disease \\
R.C. & 40 & M & Hypopituitarism \\
H.S. & 53 & M & Hypopituitarism \\
A.S. & 63 & M & Hypopituitarism \\
A.H. & 58 & M & Hypopituitarism
\end{tabular}

st day) 
Thorn (1958), and it appears that the deficient adrenal tissue is incapable of a response since it is already maximally stimulated by endogenous corticotrophin.

HYPOPITUITARISM Table II also shows the results obtained in four cases of hypopituitarism. These patients had all received either radiotherapy or surgical treatment for a pituitary tumour. Low or absent control values were again found but in contrast with the primary adrenal insufficiency of Addison's disease, an increase after corticotrophin was obtained, although this was not definitely apparent in every case until the second day of stimulation.

EFFECT OF STEROID THERAPY The well-known inhibitory effect of corticosteroid therapy on the adrenal cortex has been investigated (Table III). Tests were carried out on the day following discontinuation of the drug. The large doses of steroids administered to patients E.P. and F.S. resulted in complete adrenal inhibition, and $75 \mathrm{mg}$. of cortisone given over a longer period to W.B. also caused marked suppression. On the other hand, E.W., who was receiving $12.5 \mathrm{mg}$. of cortisone, after previously having been given much higher doses, now appeared to have normal adrenal function.

\section{DISCUSSION}

The results demonstrate that in the presence of normal adrenal function plasma 17-hydroxycorticoids were increased beyond doubt four hours after an intramuscular injection of corticotrophin zinc. The values obtained by means of the simplified procedure are comparable with those of Eik-Nes et al. (1954) and Bayliss and Steinbeck (1954) who used a more complicated technique for the estimation of plasma 17-hydroxycorticoids and an intravenous infusion of corticotrophin.
The lack of response in the primary adrenal failure of Addison's disease differentiates this condition from adrenal insufficiency secondary to hypopituitarism in which a somewhat sluggish increase in plasma steroids was obtained. Although a definite increase occurred on the second day of stimulation in the cases studied, it is conceivable that the response of some patients may be further delayed and an even longer period when corticotrophin is given may be required.

The adrenal insufficiency which accompanies steroid therapy is an important clinical problem. The results obtained in this investigation showed that adrenal suppression occurred when steroids equivalent to a daily dosage of $75 \mathrm{mg}$. or more of cortisone were given. Christy, Wallace, and Jailer (1956) have emphasized that after stopping the drug the length of time required before recovery depends upon the duration of therapy as well as the dosage, although considerable variation exists in individual patients. This aspect has not been studied in detail here, but one patient had recovered normal adrenal function within three weeks of reducing the dosage to $12.5 \mathrm{mg}$. of cortisone daily after receiving presumably suppressive doses for seven years. It should be remembered, however, that a normal response to exogenous corticotrophin does not necessarily imply complete recovery of the whole pituitaryadrenal system.

The use of plasma 17-hydroxycorticoid levels can give a more direct indication of adrenal cortical function than can be obtained from urinary 17ketosteroid and 17-ketogenic steroid values, since the latter are largely a measure of steroid metabolites and may be affected by such extra-adrenal factors as hepatic or renal disease; in these conditions abnormally low values may be encountered when plasma levels remain within the normal range.

The method which is described above for the estimation of plasma 17-hydroxycorticoids is reliable

\section{TABLE III}

RESPONSE OF PLASMA 17-HYDROXYCORTICOIDS AFTER STEROID THERAPY

\begin{tabular}{|c|c|c|c|c|c|c|c|}
\hline \multirow[t]{2}{*}{ Case } & \multirow[t]{2}{*}{ Age } & \multirow[t]{2}{*}{ Sex } & \multirow[t]{2}{*}{ Diagnosis } & \multirow[t]{2}{*}{ Steroid Therapy } & \multicolumn{3}{|c|}{ 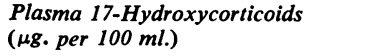 } \\
\hline & & & & & Control & $\begin{array}{l}\text { A.C.T.H. } \\
\text { (1st day) }\end{array}$ & $\begin{array}{l}\text { A.C.T.H } \\
\text { (2nd day) }\end{array}$ \\
\hline E.P. & 23 & $\mathbf{F}$ & Carcinoma colon & $\begin{array}{l}\text { Triamcindone, } 32 \mathrm{mg} \text {. daily for } \\
3 \text { months }\end{array}$ & 0 & 0 & \\
\hline $\begin{array}{l}\text { F.S. } \\
\text { W.B. } \\
\text { F.P. }\end{array}$ & $\begin{array}{l}62 \\
55 \\
60\end{array}$ & $\begin{array}{l}\mathbf{F} \\
\mathbf{F}\end{array}$ & $\begin{array}{l}\text { Behcet's disease } \\
\text { Rheumatoid arthritis } \\
\text { Treated in error as Addison's }\end{array}$ & $\begin{array}{l}\text { Prednisone, } 30 \mathrm{mg} \text {. daily for } 5 \text { weeks } \\
\text { Cortisone, } 75 \mathrm{mg} \text {. daily for } 3 \text { years } \\
\text { Cortisone, } 37.5 \mathrm{mg} \text {. daily for }\end{array}$ & $\begin{array}{l}0 \\
6\end{array}$ & $\begin{array}{l}0 \\
9\end{array}$ & \\
\hline E.W. & 44 & $\mathbf{F}$ & $\begin{array}{l}\text { disease } \\
\text { Rheumatoid arthritis }\end{array}$ & $\begin{array}{l}3 \text { years } \\
\text { Cortisone, } 12 \cdot 5 \mathrm{mg} \text {. daily for } 3 \text { weeks } \\
\text { (previously } 75-100 \mathrm{mg} \text {. daily for } \\
7 \text { years) }\end{array}$ & 11 & 17 & 31 \\
\hline
\end{tabular}


and relatively easy to perform, so that a dozen estimations can be carried out in a period of three hours, excluding the time required for the colour development. The convenience and simplicity of this corticotrophin zinc test is such that patients in whom the diagnosis of adrenal insufficiency is clinically suggestive can receive a preliminary assessment of their adrenal cortical capacity even on an out-patient basis.

This work was carried out while I was in receipt of a research grant from the Governors of St. George's Hospital.

I wish to thank Professor A. C. Dornhorst for helpful criticism, and the physicians of the hospital for permission to investigate their patients.
REFERENCES

Abu Haydar, N., St. Marc, J. R., Reddy, W. J., Laidlaw, J. C., and Thorn, G. W. (1958). J. clin. Endocr., 18, 121.

Bayliss, R. I. S., and Steinbeck, A. W. (1954). Brit. med. J., 1, 486. Christy, N. P., Wallace, E. Z., and Jailer, J. W. (1956). J. clin. Endocr. $\frac{\bar{\sigma}}{\bar{\sigma}}$
16, 1059 .

Eik-Nes, K., Sandberg, A. A., Migeon, C. J., Tyler, F. H., andD Samuels, L. T. (1955). Ibid, 15, 13.

- $\frac{-}{-}$ Nelson, D. H., Tyler, F. H., and Samuels, L. T. (1954) J. clin. Invest., 33, 1502.

Geller, J., Gabrilove, J. L., and Soffer, L. J. (1957). J. clin. Endocr. $\overrightarrow{0}$ $17,390$.

Jenkins, J. S. (1958). J. clin. Path., 11, 78.

Nelson, D. H., and Samuels, L. T. (1952). J. clin. Endocr., 12, 519.

Peterson, R. E., Karrer, A., and Guerra, S. L. (1957). Analyt. Chem. 29, 144.

- -, Wyngaarden, J. B., Guerra, S. L., Brodie, B. B., and Bunim; J. J. (1955). J. clin. Invest., 34, 1779.

Porter, C. C., and Silber, R. H. (1950). J. biol. Chem., 185, 201.

Silber, R. H., and Porter, C. C. (1954). Ibid., 210, 923. 